\title{
Non-Associative Learning and Serotonin Induce Similar Bi- Directional Changes in Excitability of a Neuron Critical for Learning in the Medicinal Leech
}

\author{
Brian D. Burrell, ${ }^{1}$ Christie L. Sahley, ${ }^{3}$ and Kenneth J. Muller ${ }^{1,2}$ \\ ${ }^{1}$ Department of Physiology and Biophysics and 2Neuroscience Program, University of Miami School of Medicine, Miami, \\ Florida 33136, and '3epartment of Biological Sciences, Purdue University, West Lafayette, Indiana 47907
}

In studies of the cellular basis of learning, much attention has focused on plasticity in synaptic transmission in terms of transmitter release and the number or responsiveness of neurotransmitter receptors. However, changes in postsynaptic excitability independent of receptors may also play an important role. Changes in excitability of a single interneuron in the leech, the S-cell, were measured during non-associative learning of the whole-body shortening reflex. This interneuron was chosen because it is known to be necessary for sensitization and full dishabituation of the shortening response. During sensitization, S-cell excitability increased, and this enhancement corresponded to facilitation of the shortening reflex and increased S-cell activity during the elicited response. During habituation training, there was a decrement in both the shortening reflex and the elicited S-cell activity, along with decreased S-cell excitability. Conversely, dishabituation facilitated both the shortening response and S-cell activity during shortening, with an accompanying increase in S-cell excitability. Bath application of 1-10 $\mu \mathrm{M}$ serotonin (5HT), a modulatory neurotransmitter that is critical for sensitization, for full dishabituation, and for associative learning, increased S-cell excitability. S-cell excitability also increased after stimulation of the serotonergic Retzius cells. However, focal application of serotonin onto the S-cell soma hyperpolarized the interneuron, and bath application of a lower dose of serotonin $(0.1 \mu \mathrm{M})$ decreased excitability. The observed changes in postsynaptic excitability appear to contribute to non-associative learning, and modulatory neurotransmitters, such as serotonin, evidently help regulate excitability. Such changes in S-cell excitability may also be relevant for more complex, associative forms of learning.

Key words: leech; serotonin; learning; sensitization; habituation; neuron excitability
Studies of the cellular basis of learning focus frequently on presynaptic and postsynaptic modulation of chemical synaptic transmission (for review, see Hawkins et al., 1993; Malenka and Nicoll, 1999); although undoubtedly critical, changes in the synapses themselves are not the only mechanisms that contribute to learning. For example, there may be changes in neuron excitability through the actions of modulatory neurotransmitters, such as serotonin $(5 \mathrm{HT})$ or acetylcholine. 5HT contributes to learning in a wide range of organisms, including the medicinal leech. Depletion of 5HT from the leech CNS disrupts sensitization (nonassociative behavioral enhancement, usually induced by noxious stimulus) of the whole-body shortening response, but it does not affect performance of whole-body shortening or habituation (a reversible decrease in response magnitude induced by repetitive stimulation) of this reflex. 5HT depletion partially disrupts dishabituation (non-associative enhancement of a habituated response) and associative learning of this behavior (Ehrlich et al., 1992; Sahley, 1994).

Significantly, the effects of 5HT depletion on non-associative learning in the leech are identical to those observed when a single

Received April 18, 2000; revised Nov. 21, 2000; accepted Dec. 5, 2000.

This work was supported by National Research Service Award FS-NS10065 (B.D.B), Lois Pope LIFE Fellowship (B.D.B.), and National Institutes of Health Grant R01-NS34927. We thank Eric Wu and two anonymous reviewers for their helpful comments during the preparation of this manuscript.

Correspondence should be addressed to Dr. Brian D. Burrell, Department of Physiology and Biophysics, University of Miami School of Medicine, 5088 Rosenstiel Building (R-430), 1600 NW 10th Avenue, Miami, FL 33136. E-mail: bburrell@ chroma.med.miami.edu.

Copyright (C) 2001 Society for Neuroscience 0270-6474/01/211401-12\$15.00/0 interneuron, the S-cell, is lesioned. Each segmental ganglion of the leech has one S-cell with a bifurcating axon, one branch extending into the anterior connective and the other extending into the posterior connective; each branch forms an electrical synapse with the S-cell axon from a neighboring ganglion. If this linked chain of interneurons is broken, either by destruction of a single S-cell or simply by cutting the axon of a single S-cell, sensitization of the whole-body shortening reflex is completely disrupted and dishabituation is partially disrupted, whereas habituation and the capacity to carry out whole-body shortening are unaffected (Sahley et al., 1994; Modney et al., 1997; Shaw and Kristan, 1999).

The whole-body shortening of the leech is a defensive withdrawal reflex triggered by photic or mechanosensory stimuli and involving contraction of all body segments nearly simultaneously. The mechanosensory stimuli that elicit shortening activate touch (T) and pressure (P) sensory neurons and, for stronger stimuli, nociceptive (N) cells (Fig. 1) (Shaw and Kristan, 1995). Sensory input activates two intersegmental neural pathways (Shaw and Kristan, 1995, 1999), the S-interneurons and a second, parallel interneuron pair [recently identified as R3Sh by Esch and Kristan (1999)] situated in the head ganglion and extending along the nerve cord. Sensory and interneuron inputs excite motor neurons that in turn excite the longitudinal muscles causing whole-body shortening (Fig. 1). Although S-cell activity is consistently observed during whole-body shortening (Magni and Pelligrino, 1978) and corresponds with L motor neuron output during shortening (Shaw and Kristan, 1995, 1999), shortening is not triggered by S-cell stimulation alone (Gardner-Medwin et al., 1973; Shaw 


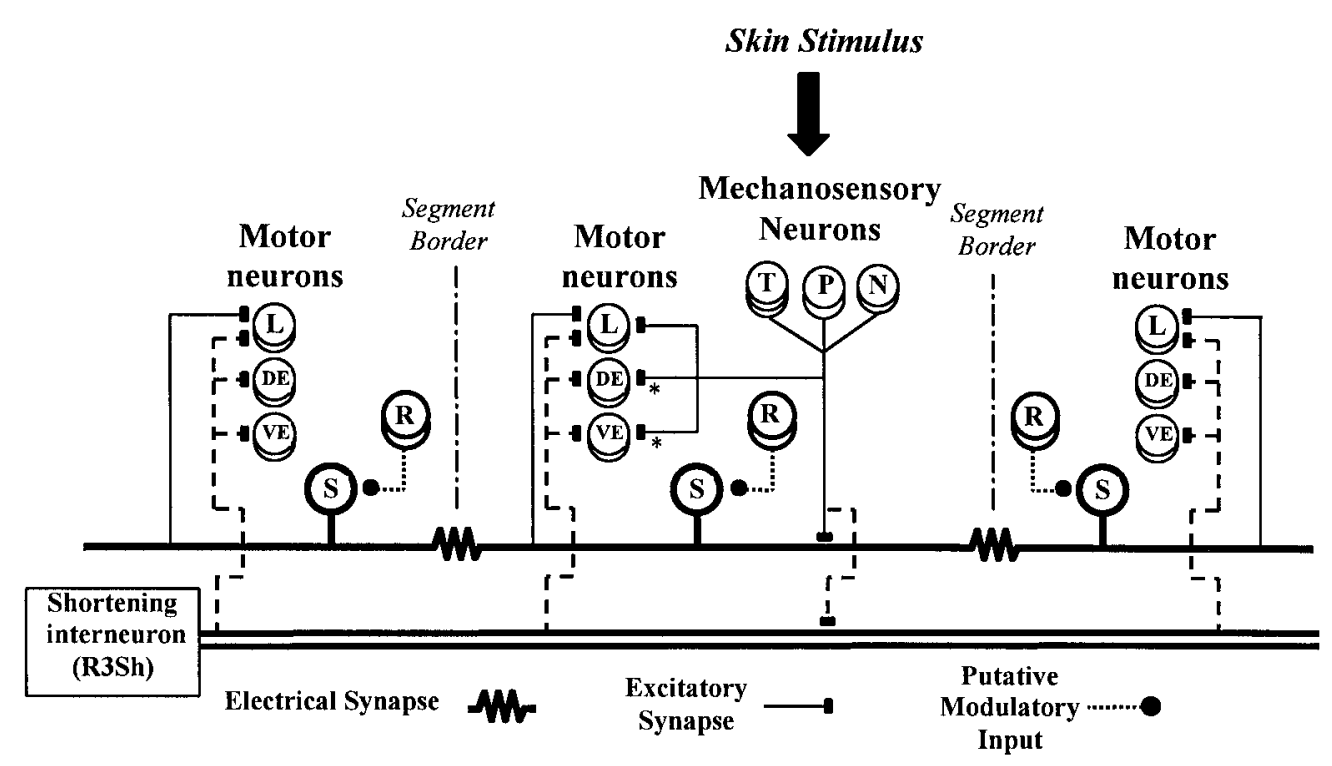

Figure 1. Neural circuit of the leech whole-body shortening reflex. Mechanosensory input to the skin is transduced by touch $(T)$, pressure $(P)$, and nociceptive $(N)$ cells, which excite the longitudinal $(L)$, dorsal exciter $(D E)$, and ventral exciter $(V E)$ motor neurons that induce contraction of the longitudinal muscles. The signal to shorten is carried to motor neurons throughout the body by the S-cell and a parallel interneuron known as the R3Sh cell located in the leech head ganglion and, unlike the S-cell, is bilaterally paired (Esch and Kristan, 1999). The sensory input pathways to R3Sh and the excitatory pathways from this interneuron to the motor neurons (dashed lines) are hypothetical. Although the S-cell is active during shortening and has excitatory input onto the L motor neuron (Gardner-Medwin et al., 1973; Magni and Pelligrino, 1978), the S-cell is not necessary for whole-body shortening, but instead is critical for plasticity of this behavior (see introductory remarks). The Retzius $(R)$ cells contain 5 HT. Connections marked by asterisk are polysynaptic.

and Kristan, 1995) and, as stated earlier, is not dependent on the presence of an intact S-cell chain. Nevertheless, experimental evidence shows that the S-cell is essential for plasticity of this behavior and that sensitization increases S-cell activity elicited during shortening and the contribution made by the interneuron to the behavior (Sahley et al., 1994).

Given the similarity in the effects of 5HT depletion and S-cell lesions on non-associative learning, the interaction between 5HT and S-cell activity was examined. The S-cell is not serotonergic itself, so it is reasonable to hypothesize that 5HT modulates the S-cell in a way that would enhance its activity. Changes in S-cell excitability were monitored during sensitization, habituation, and dishabituation of whole-body shortening, and the effects of 5HT on S-cell excitability were tested.

\section{MATERIALS AND METHODS}

Leeches (2-3 gm) were obtained from a commercial supplier (Leeches USA, Westbury, NY) and maintained in artificial pond water $(0.5 \mathrm{gm}$ Forty Fathoms/1 $1 \mathrm{H}_{2} \mathrm{O}$; Marine Enterprises, Baltimore, MD) in a refrigerated incubator at $18-20^{\circ} \mathrm{C}$. Except where noted, all experiments were performed in leech saline solution consisting of (in mM): $115 \mathrm{NaCl}$, $4 \mathrm{KCl}, 1.8 \mathrm{CaCl}_{2}$, and 10 Tris-maleate, at $\mathrm{pH} 7.4$ (Kuffler and Potter, 1964). In some experiments, $15 \mathrm{Mg}^{+2}$ replaced $\mathrm{Na}^{+}$mole for mole. S-cells were identified by (1) location on the ganglion ventrum in the central neuropil packet close to the Retzius (R) cells, (2) one of the larger "small" cells, $\sim 15 \mu \mathrm{m}$ in diameter, and (3) a rapid, overshooting action potential with few if any IPSPs. For electrophysiological measurements, the soma was impaled with a thin-walled, glass microelectrode (0.75 mm inner diameter; Frederick-Haer, Brunswick, ME) filled with 4 $\mathrm{M}$ potassium acetate and having a $15-20 \mathrm{M} \Omega$ resistance. Signals were amplified with a Getting $5 \mathrm{~A}$ electrometer and viewed on a storage oscilloscope (Tektronix, Wilsonville, OR). Extracellular recordings from suction electrodes were made using a Grass P15 A.C. preamplifier. Physiological data were filtered (Ithaco 4302 dual $24 \mathrm{~dB} /$ octave filter) and converted for digital storage and future analysis using Axotape and Axoscope data acquisition software with a Digidata 1200 series interface (Axon Instruments). Controlled stimulus pulses were delivered using a Grass S88 two-channel stimulator with SIU5 stimulus isolation units. All behavioral and physiological experiments were conducted at room temperature.

Behavioral experiments. Sensitization and habituation/dishabituation experiments were performed on a variation of the "quasi-intact" preparation used in previous studies of non-associative learning in the leech (Burrell and Sahley, 1998). Animals were anesthetized by cooling at $4^{\circ} \mathrm{C}$ in artificial pond water and then transferred to a Sylgard-lined (Dow Corning) dissecting dish that was surrounded by a layer of ice. All dissections were performed in ice-cold leech saline. An incision was made along the dorsal midline between segments 3 and 6 , where intracellular recordings from single S-cells were to be made during training. The next three posterior segments (7-9) remained intact and were later used to measure the whole-body shortening reflex. In segments 10-13, the CNS (ganglia and connective nerve) was exposed completely, and the body was dissected away, with the nerve cord cut anterior of ganglion 14, which was removed with the posterior portion of the animal. A suction electrode applied to the exposed posterior end of the nerve cord was used to monitor S-cell activity during elicited whole-body shortening responses.

The preparation was pinned ventral side up to a Sylgard-lined dish $(12.5 \times 4.5 \times 2.0 \mathrm{~cm})$ filled with $\sim 10 \mathrm{ml}$ ice-cold saline. This dish could fit within the ice-filled dissecting dish, allowing dissections to be ice-cold at every stage. The anterior portion of the preparation (segments 3-6) was pinned to form a flat sheet. A pair Teflon-coated silver wires (uncoated diameter $0.125 \mathrm{~mm}$; AM Systems) was implanted in the skin at segment 4 on both sides of the ventral midline and bared at the point of contact with the skin. These wires, connected to the stimulator, delivered electroshocks to discrete portions of the leech skin to elicit reflexive shortening. All measurements of shortening magnitude and S-cell activity during the learning experiments were of responses elicited by the segment 4 electrodes. A second pair of electrodes was implanted in a similar manner at segment 8 (the intact portion of the preparation) and was used to deliver sensitizing or dishabituating stimuli to the preparation. A small, longitudinal incision was made on the ventral side of segment 4 , providing a window that allowed the segment 4 ganglion to be viewed and individual neurons within this ganglion to be recorded from. The intact portion of the preparation was connected to a tension transducer (Grass Instruments) using a 6-0 nylon monofilament (Henry Schein). When a whole-body shortening response was elicited, the intact portion of the preparation shortened, pulling on the tension transducer and producing a measurable whole-body shortening response. 

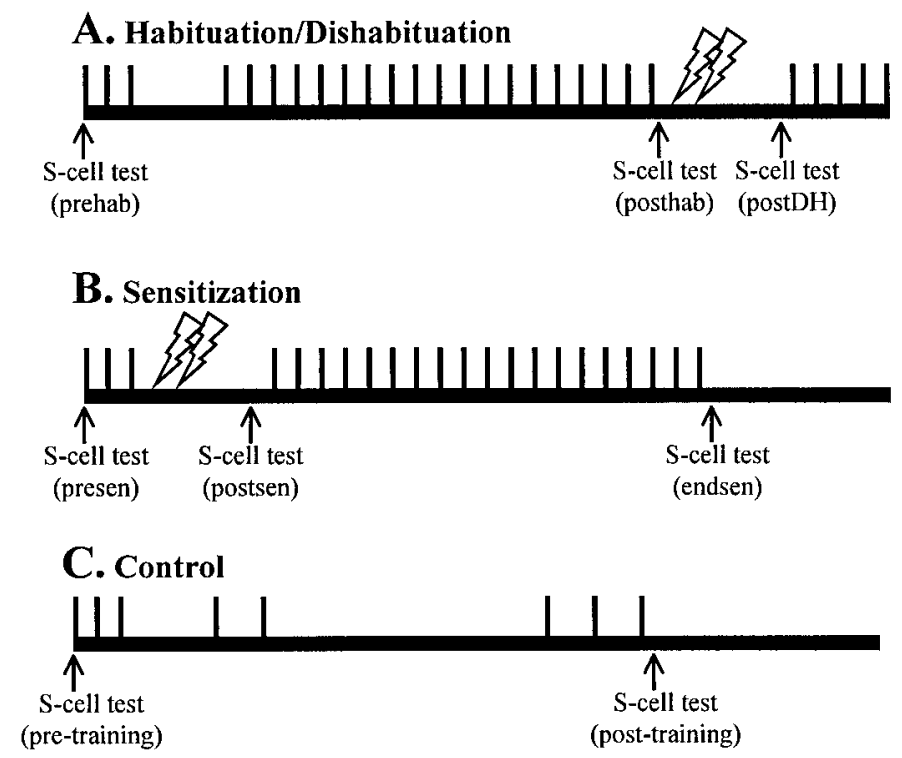

Figure 2. Training protocol for non-associative learning experiments. Each vertical line represents a single stimulus-response trial in which a mechanosensory stimulus (a single electroshock) was used to elicit a whole-body shortening response. ITIs are 2 min unless noted otherwise. Lightning bolt symbols represent noxious stimuli (trains of electroshock pulses) used to sensitize or dishabituate a preparation. For all training conditions, the S-cell excitability and input resistance were measured (prehab, presen, and pre-training $S$-cell test) followed by three stimulusresponse trials to establish a baseline shortening response for that preparation. $A$, Preparations were habituated by repetitive mechanosensory stimuli and dishabituated by noxious stimuli. Additional S-cell measurements were made after habituation training (posthab) and after dishabituation (postDH). B. Preparations were sensitized by noxious stimuli. Additional S-cell measurements were made after delivery of the noxious stimuli (postsen) and after repetitive stimulation (endsen). $C$, After the baseline test, control preparations were stimulated at 4 min ITIs at time points that corresponded to the beginning and end of the habituation training period. S-cell measurements were made before baseline stimulation (pre-training) and at the end of the pseudo-training period (post-training).

The stimulus was a single capacity-coupled $1.5 \mathrm{msec}$ pulse of current delivered through the skin-implanted electrodes. The stimulus magnitude ranged from 1.5 to $6.0 \mathrm{nA}$ and was set for each preparation at the behavioral threshold, that stimulus level which elicited robust shortening and S-cell activity with repeated stimulation (two to three stimuli at 3 min intervals). This procedure was performed both for the test stimulus electrodes (segment 4) and for those that delivered the sensitizing or dishabituating stimuli. Once the stimulus threshold for each preparation had been determined, training was started 15-20 min later.

With each preparation, one of two types of non-associative training procedures was performed: habituation/dishabituation or sensitization. First, a baseline magnitude of the whole-body shortening response was determined for each preparation by taking the average of three elicited shortening responses [ 2 min intertrial interval (ITI)]. Four minutes after establishing the baseline response level, the skin of preparations in the habituation/dishabituation group $(n=12)$ was stimulated repetitively (20 pulses, 2 min ITI) (Fig. $2 A$ ). This was followed by a series of dishabituating stimuli, consisting of two trains of electroshocks $(1.5 \mathrm{msec}$ pulse duration, $1.0 \mathrm{sec}$ train duration, $10 \mathrm{~Hz}$ intratrain stimulus frequency, 2 min intertrain interval) applied at segment 8 . Four minutes after delivery of the dishabituating stimuli, the shortening reflex was retested with five single stimulus-response trials ( 2 min ITI). Preparations in the sensitization training group $(n=10)$ were stimulated with two trains of electroshocks identical to those used for dishabituation, 4 min after the baseline response level was obtained (Fig. $2 B$ ). After a 4 min rest period, the behavioral responses of the preparations were tested by delivering 20 repetitive skin stimuli having the same parameters as for habituation training. A third group was a control $(n=6)$ to determine whether the behavioral response remained unchanged with time. After the baseline response was established, 4 min were allowed to pass before the preparation was stimulated twice at a time corresponding to the beginning of habituation training and three times at the time point that corresponded with the end of habituation training (Fig. $2 C$ ). The number of stimulation trials was minimized, and the ITI was increased to $4 \mathrm{~min}$ to prevent habituation of these preparations.

Intracellular recordings were made from the segment-4 S-cell at various times during behavioral training procedures to test for changes in excitability of this interneuron (Figs. $2 A-C$ ). Excitability of the S-cell was measured using two techniques. The first involved measuring the amount of current injected through the intracellular electrode necessary to elicit a single action potential, the action potential initiation threshold. This threshold was measured by injecting a $20 \mathrm{msec}$ pulse into the S-cell soma and adjusting the depolarizing current until the stimulus reliably elicited an action potential within the first $10-15 \mathrm{msec}$ of the stimulus pulse. The second measure of excitability was the number of action potentials elicited by a $200 \mathrm{msec}$ depolarizing pulse at the same level as the threshold with the $20 \mathrm{msec}$ pulse at the onset of the experiment. In addition, S-cell input resistance was measured using a $200 \mathrm{msec}$ pulse of hyperpolarizing current. During the initial test of excitability, membrane voltage was hyperpolarized using small amounts of current to prevent the S-cell from firing action potentials as a result of spontaneous EPSPs. This membrane voltage was maintained for all subsequent measurements of excitability. Excitability in each group was tested before baseline measurements of behavior. S-cell measurements were made in the habituation group immediately after habituation training (posthab test) and after delivery of the dishabituating stimuli (postDH test). In the sensitization group, S-cell excitability was tested immediately after delivery of sensitizing stimuli (postsen test) and at the end of repetitive stimulation (endsen test). S-cells in the control group were tested at the end of the pseudo-training period (post-training test).

Concentration series. To test the effects of various concentrations of $5 \mathrm{HT}$ on S-cell excitability, a single ganglion was dissected from the animal, desheathed using a pair of fine scissors, and placed in a Sylgardlined recording chamber filled to $\sim 300 \mu \mathrm{l}$ with leech saline. Measurements of S-cell excitability were made as described, except that the stimulus pulse durations for the threshold measurements and for eliciting the train of action potentials were 25 and $250 \mathrm{msec}$, respectively. Both measures of S-cell excitability were made before, during, and at regular intervals after 5HT application. 5HT (Sigma, St. Louis, MO) was applied to the leech ganglion by rapidly exchanging the leech saline with $1 \mathrm{ml}$ of saline containing $0.1 \mu \mathrm{M}(n=7), 1.0 \mu \mathrm{M}(n=7)$, or $10.0 \mu \mathrm{M}(n=4) 5 \mathrm{HT}$. After the 2 min treatment, the 5HT-containing saline was replaced with normal saline; fresh saline was then inf used at 4 min intervals for the rest of the experiment. Changes in S-cell excitability in the 5HT-treated groups were compared with measurements taken from control S-cells $(n=5)$ that were treated with normal leech saline without 5HT.

Metal microelectrode experiments. A two-ganglion chain was dissected, with one ganglion desheathed using fine scissors. The chain was placed in a $200 \mu \mathrm{l}$ chamber through which leech saline flowed at $\sim 2 \mathrm{ml} / \mathrm{min}$. In these experiments, an extracellular electrical stimulus was selectively applied to the S-cell soma using a metal microelectrode similar to those used to stimulate cultured Retzius cells (Grumbacher-Reinert and Nicholls, 1992). The electrode was fabricated by electro-etching $0.1-\mathrm{mm}$ diameter tungsten wire in a saturated solution of aqueous $\mathrm{KNO}_{2}$ to sharpen it and coating all but the very tip of the wire with Stoner-Mudge package coating (Mobil) (Hubel, 1957).

The tip of the metal microelectrode was placed in direct contact with the S-cell soma located in the desheathed ganglion, and capacity-coupled stimulus pulses $(2.5 \mathrm{msec})$ were delivered selectively to that neuron. Intracellular recordings of nearby neurons confirmed that stimuli from the metal microelectrode elicited action potentials in only the S-cell (data not shown). The connective nerve at the far end of the two-ganglion chain was sucked into a suction electrode, and recordings made to observe any S-cell action potentials elicited by the metal microelectrodedelivered stimulus pulse. The S-cell axon produces the largest signal in these recordings, and its action potential is easily distinguished from the other activity in connective nerve (Laverack, 1969; Bagnoli et al., 1972). A baseline threshold was determined as that current reliably eliciting an action potential when the pulse was given three times in a row at $5 \mathrm{sec}$ intervals. Then $1.0 \mu \mathrm{M}$ 5HT was perfused through the chamber, and the action potential initiation threshold was retested. In one group 5HT was applied to the tissue for $2 \min (n=6)$, whereas a second group received a 4 min 5HT treatment $(n=6)$. At the end of the 5HT application, the flow was returned to normal leech saline, and the action potential 
initiation threshold was tested at regular intervals for $1 \mathrm{hr}$. The S-cell responses from these two 5HT-treated groups were compared with those from a control group $(n=7)$ tested in normal leech saline for an equivalent period. A third experiment comparing the effects of the $4 \mathrm{~min}$ 5HT $(n=7)$ application to a control group $(n=6)$ was made in $15 \mathrm{~mm}$ $\mathrm{MgCl}_{2}$ leech saline to block chemical synaptic transmission (Nicholls and Purves, 1970). Measurements of initiation threshold were made throughout at 2 min intervals in normal saline for $6 \mathrm{~min}$, then in $15 \mathrm{~mm} \mathrm{MgCl}{ }_{2}$ saline for $20 \mathrm{~min}$. Next the tissue was continuously bathed in $1.0 \mu \mathrm{M} 5 \mathrm{HT}$ in $15 \mathrm{mM} \mathrm{MgCl}_{2}$ saline for $4 \mathrm{~min}$, after which the $5 \mathrm{HT}$ was washed out with a constant flow of $15 \mathrm{~mm} \mathrm{MgCl}_{2}$ saline. For control experiments, $5 \mathrm{HT}$ was omitted.

Retzius cell stimulation. Single ganglia were placed in an $80 \mu \mathrm{l}$ chamber in normal leech saline. Both the S-cell and a single R-cell (which is the main type of serotonergic neuron in the leech CNS) were impaled with glass microelectrodes for intracellular recording and stimulation. Excitability and input resistance of the S-cell were tested as usual; then the R-cell was stimulated at a rate of $3-4 \mathrm{~Hz}$ with a $20 \mathrm{msec}$ pulses of depolarizing current for $10 \mathrm{sec}(n=6)$. The firing rate was similar to that used by Willard (1981), who stimulated longer (5-10 $\mathrm{min}$ ). The stimulation parameters were not meant to precisely mimic the amount of 5HT delivered by bath application or putatively released by sensitizing stimulus, but simply to test the effects of endogenously released 5HT. S-cell threshold and input resistance were measured immediately after and at 5 and 10 min after R-cell stimulation. Changes in S-cell properties in this high-frequency R-cell-stimulated group were compared with those in S-cells when the R-cell was stimulated at only $0.3 \mathrm{~Hz}$ for $10 \mathrm{sec}(n=4)$.

Focal application of 5HT. 5HT was focally applied to the S-cell soma in desheathed single ganglia using the $200 \mu \mathrm{l}$ chamber used for the metal microelectrode experiments with a constant flow of $15 \mathrm{mM} \mathrm{MgCl}$ saline at a rate of $\sim 0.5 \mathrm{ml} / \mathrm{min}$. Thin-walled glass micropipettes were filled with $50 \mathrm{~mm} 5 \mathrm{HT}$ in leech saline with $0.2 \%$ Fast Green, and their tips were beveled to a resistance of 20-30 $\mathrm{M} \Omega$. During intracellular recording from the S-cell, the 5HT-containing electrode was placed close (5-10 $\mu \mathrm{m})$ to the cell soma, and the colored 5HT solution was expelled from the tip at a pressure of $20 \mathrm{psi}$ for $1 \mathrm{sec}$ with a Picospritzer (General Valve, Fairfield, NJ) $(n=6)$. In control experiments 5HT was omitted from the pipette solution $(n=4)$.

Statistical analysis. Behavioral and physiological data were normalized to a baseline value obtained at the beginning of the experiment for each preparation. Behavioral and S-cell activity data from the non-associative learning experiments were collapsed into trial blocks, with each block consisting of the average from five stimulus-response trials. Statistical analysis was performed using one-way and two-way ANOVA, as well as independent and paired $t$ tests using the Statistica analysis software (Statsoft). Two-way ANOVA was used to analyze (1) the effects of the different training groups (sensitization or habituation), (2) the effects of different time points during the training protocol when a particular behavioral or physiological component was tested (know in the text as trial block or experimental stage effect), and (3) the interaction of these two effects. All post hoc analyses used the least significant difference test for planned comparisons. All data are presented as the mean \pm SE.

\section{RESULTS}

\section{Effects of non-associative learning on behavior and S-cell activity}

During habituation training, the magnitude of the whole-body shortening response substantially decreased across the four trial blocks during which repetitive stimuli were delivered (Fig. 3). This decrease in the shortening was not simply the result of the passage of time, because the behavioral response in the control group did not change during a comparable time period. A twoway ANOVA comparing the habituation and control group behavioral responses from trial blocks 1 and 4 demonstrated a statistically significant group effect $\left(F_{(1,38)}=6.35 ; p<0.05\right)$, no significant trial effect $\left(F_{(1,38)}=0.16\right)$, and a significant group/trial interaction effect $\left(F_{(1,38)}=4.74 ; p<0.05\right)$. Post hoc analysis of the interaction effect confirmed that in the habituation group the behavioral response during trial block 4 was significantly lower than that of trial block $1(p<0.05)$. Furthermore, the response level during trial block 4 in the habituation group was significantly

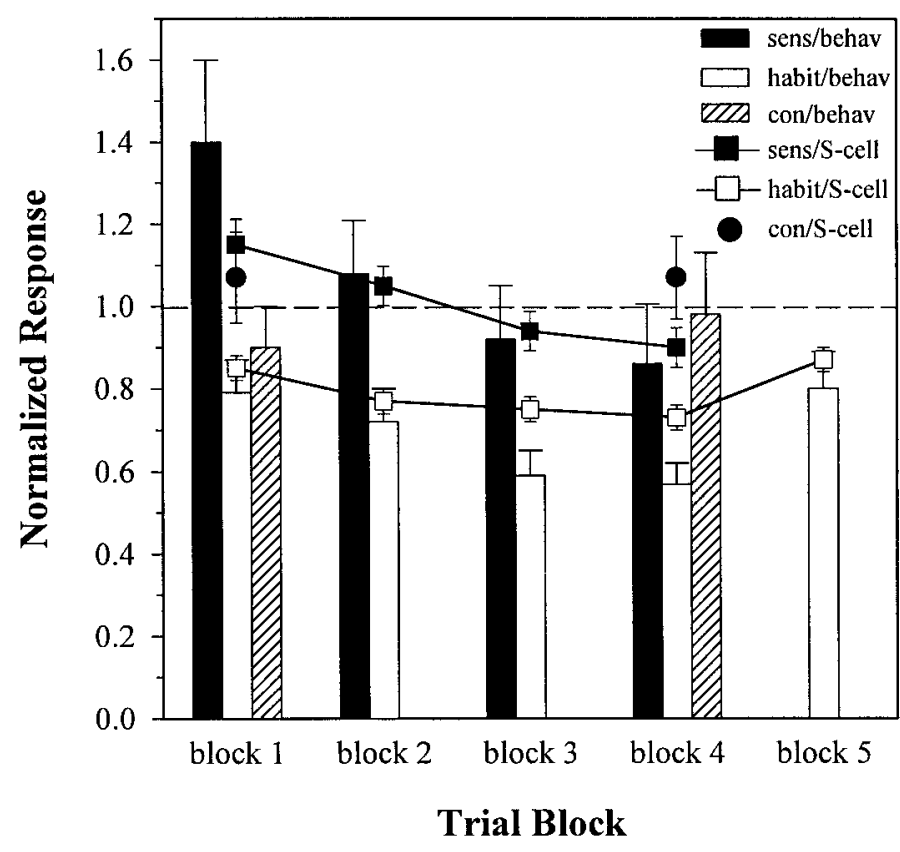

Figure 3. Effects of sensitization, habituation, and dishabituation on whole-body shortening (bar plots) and S-cell activity (line/point plots) during shortening. Data are presented as the mean \pm SE of the normalized response at each trial block. Each trial block represents the average of five stimulus-response trials and was normalized to an initial response measure made before training. The broken horizontal line represents the initial baseline level for each response measure.

lower than that of the control group $(p<0.01)$. There were no significant differences in behavior between trial 1 and 4 in the control group and no differences in response level during trial block 1 between the habituation and control groups.

S-cell activity during an elicited whole-body shortening response was also lower in preparations from the habituation group compared with the control group (Fig. 3). A two-way ANOVA of activity levels of trial blocks 1 and 4 in these two groups showed a significant group effect $\left(F_{(1,38)}=20.65 ; p<0.0001\right)$, but no significant trial $\left(F_{(1,38)}=0.89\right)$ or group/trial interaction effect $\left(F_{(1,38)}=1.00\right)$. The lack of a significant group/trial interaction effect precludes a post hoc analysis of how S-cell activity changed across trial blocks in the two groups, but S-cell activity in the control group did not appear to change between trial blocks 1 and 4. S-cell activity during trial block 1 was lower in the habituation group than in the control group, explaining the lack of a statistically significant interaction effect. This differs from the comparable behavioral results described above and suggests that there was a decrement in S-cell activity during this early stage of habituation training that was not observed in the corresponding behavioral response. Nevertheless, separate analysis of S-cell activity in trial blocks 1-4 of the habituation group revealed a significant decrease in activity across trial blocks (one-way ANOVA $F_{(3,92)}$ $=4.16 ; p<0.01)$, with post hoc analysis showing that S-cell activity in trial blocks 3 and 4 was significantly reduced relative to trial block $1(p<0.01)$.

The reduction in whole-body shortening during habituation training was not the result of fatigue or a reduction in the health of the preparations brought about by repetitive stimulation. This was demonstrated by dishabituation of the habituated preparations with noxious stimuli, which significantly increased the magnitude of the trial block 5 shortening reflex relative to the trial 


\section{Sensitization}

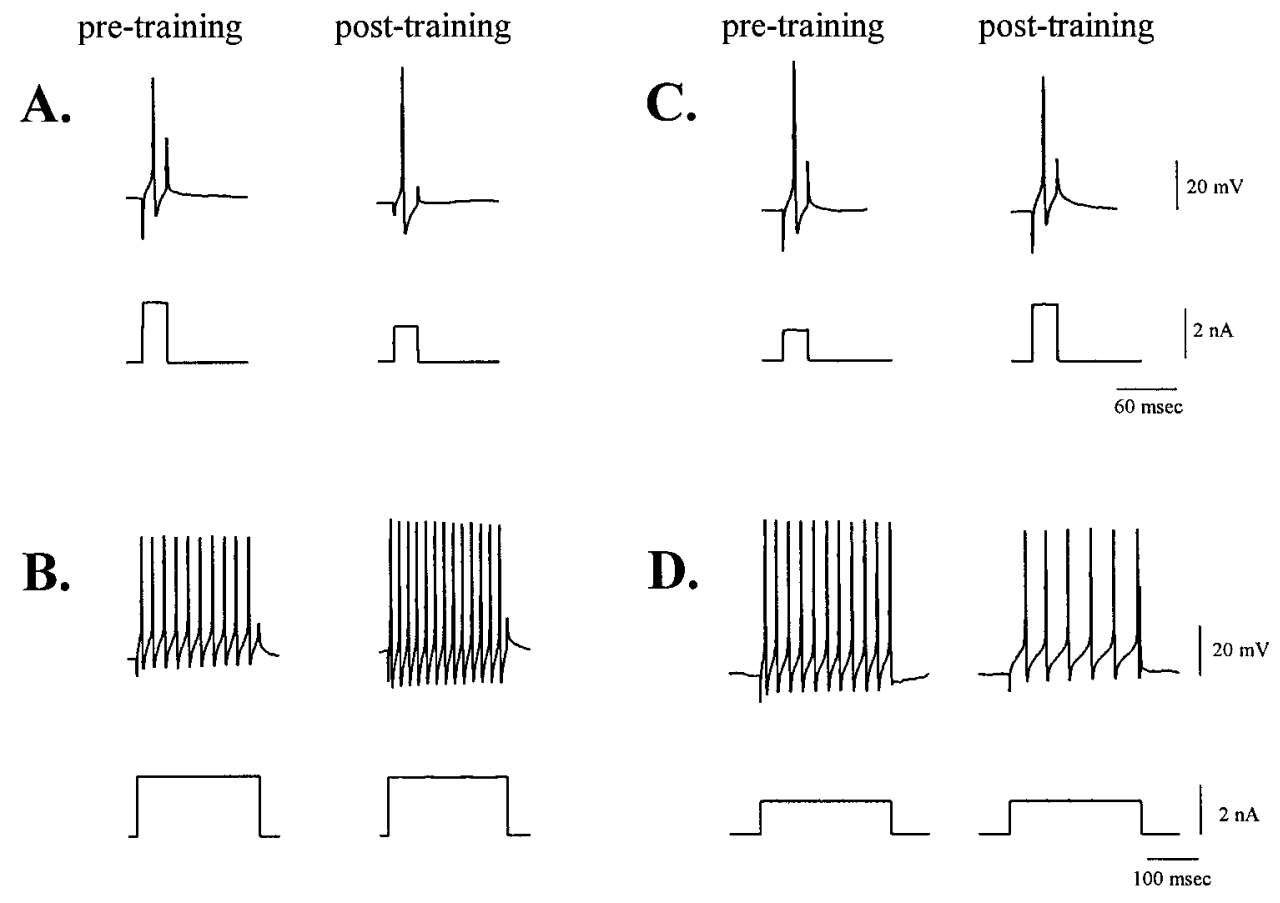

Figure 4. Examples of sensitization- and habituation-induced changes in S-cell excitability. In each set of traces, the top traces are membrane potential measurements during elicited activity, and the bottom traces are the current pulses used. Sensitization decreases $(A)$ the S-cell initiation threshold (measured as the amount of current necessary to produce a single action potential) and increases $(B)$ the number of action potentials produced by a long current pulse. Habituation increases $(C)$ the S-cell initiation threshold and decreases $(D)$ the number of action potentials elicited by the long stimulus pulse.

block 4 response (Fig. 3) (one-way ANOVA $F_{(1,26)}=4.91 ; p<$ $0.05)$. A corresponding increase in shortening-elicited S-cell activity was observed $\left(F_{(1,26)}=8.39 ; p<0.01\right)$.

During sensitization training, delivery of a noxious stimulus after the baseline experimental stage, but before the repetitive stimulus stage, produced an increase in the magnitude of wholebody shortening (Fig. 3). In addition, the shortening response did not decrease substantially below the baseline level with repeated stimulation. A two-way ANOVA confirmed that behavioral responses in the sensitized group were enhanced relative to the habituation group during trial blocks 1 through $4\left(F_{(1,88)}=24.98\right.$; $p<0.0001)$. The analysis also detected a significant effect of trial block $\left(F_{(3,88)}=4.76, p<0.01\right)$ but no group/trial interaction effect $\left(F_{(3,88)}=0.80\right)$. Post hoc analysis of the trial effect showed that the response level during trial blocks 3 and 4 was significantly lower than in trial block 1 ( $p<0.01$ and $p<0.001$, respectively) for both groups. These latter analyses indicate that, as in the case of habituation training, the shortening response in sensitized preparations decreased relative to the trial block 1 levels with repetitive stimulation. However, in the case of sensitization, the response magnitude did not decrease substantially relative to the baseline level and was still enhanced relative to the response of the habituated group.

Sensitization affected the level of shortening-elicited S-cell activity in a manner that was parallel to the observed changes in behavior (Fig. 3). Two-way ANOVA showed a significant enhancement of S-cell activity in the sensitized group across all four trial blocks relative to the preparations that were habituated $\left(F_{(1,88)}=65.08 ; p<0.00001\right)$, as well as a significant decrease in activity in both groups across trial blocks $\left(F_{(3,88)}=7.81 ; p<\right.$ 0.001). Post hoc analysis of the trial effect showed that trial block 1 activity was significantly higher when compared with trial blocks 2,3 , and 4 ( $p<0.05, p<0.01$, and $p<0.001$, respectively). There was no significant group/trial interaction effect $\left(F_{(3,88)}=1.25\right)$.

The data show that these reduced preparations underwent non-associative learning comparable with that described before with intact or semi-intact leeches, including sensitization and habituation-induced changes in behavior and S-cell responses (Ehrlich et al., 1992; Sahley et al., 1994). That the preparations could dishabituate supports the conclusion that the decreased response during habituation training was caused by plasticity at the CNS level and not by peripheral processes such as adaptation or fatigue (Thompson et al., 1973).

\section{Effects of non-associative learning on S-cell response properties}

Sensitization, habituation, and dishabituation training were all effective in altering the excitability of the S-interneuron. In sensitized preparations, the S-cell initiation threshold, measured as the amount of injected current necessary to elicit an action potential, decreased substantially after delivery of the sensitization-inducing noxious stimulus (postsen) relative to the pretraining threshold levels (Figs. $4 A, 5 A$ ). This decrease in threshold indicates that sensitization increased the excitability of the interneuron. At the end of the sensitization experiments (endsen), when the preparations had been stimulated repetitively, initiation threshold levels had returned to baseline levels. Habituation training, on the other hand, increased the initiation thresh- 


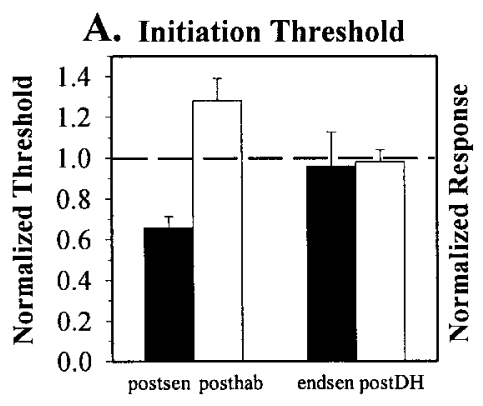

B. Number of Impulses

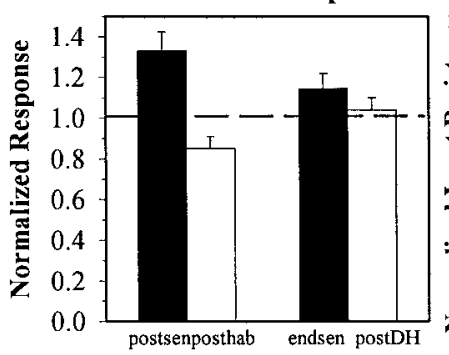

C. Input Resistance

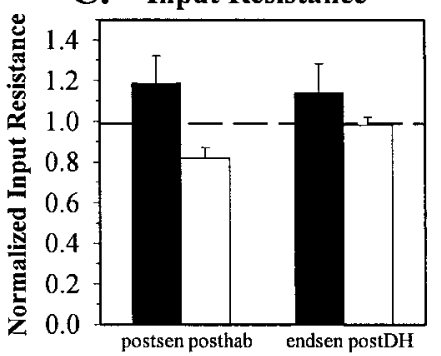

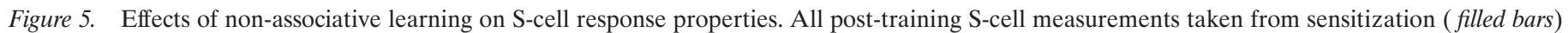

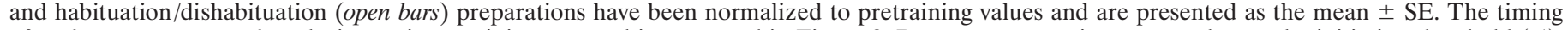

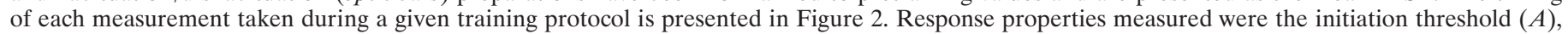
the number of action potentials fired during a $200 \mathrm{msec}$ current pulse $(B)$, and the input resistance at the soma $(C)$.

old of the S-cell relative to pretraining levels (Figs. $4 C, 5 A$ ), indicating decreased excitability (posthab). Dishabituation reversed the habituation-induced decrease in S-cell excitability, and the S-cell initiation threshold returned to prehabituation levels (Fig. 5A, post $D H$ ). A two-way ANOVA compared the differences in the normalized threshold data between the sensitization and habituation groups and between the measurements taken at different time points during training (Fig. 2). This analysis detected a significant effect of training group $\left(F_{(1,39)}=9.67 ; p<0.001\right)$, no significant effect of time $\left(F_{(1,39)}=0.36\right)$, and a significant group/ time interaction effect $\left(F\left(_{1,39)}=5.28 ; p<0.05\right)\right.$. Post hoc analysis showed that the postsen threshold was significantly lower than posthab $(p<0.001)$ and that posthab threshold was significantly higher than postDH $(p<0.05)$. Although endsen threshold appeared to return to baseline levels, the threshold level was not significantly different from postsen levels.

Nearly identical results were obtained from analysis of data from the second measure of S-cell excitability: the number of action potentials elicited from the long stimulus pulse kept at a constant magnitude. The number of action potentials increased after delivery of the noxious stimuli (Figs. $4 B, 5 B$ ) and by the end of training had returned to near baseline. Conversely, the number of elicited action potentials decreased after habituation training and returned to baseline levels after dishabituation of the shortening reflex (Figs. 4D, 5B). Two-way ANOVA confirmed the differences in this $\mathrm{S}$-cell response measure between training groups and across time with a significant effect of training group $\left(F_{(1,37)}=16.29 ; p<0.001\right)$, no significant effect of time $\left(F_{(1,37)}=\right.$ $0.43)$, and a significant group/time interaction effect $\left(F_{(1,37)}=\right.$ 4.43; $p<0.05)$. Post hoc analysis showed a significant difference in the number of elicited S-cell action potentials between the postsen and posthab tests $(p<0.0001)$. There was also a significant decrease in the number of elicited S-cell action potentials during the endsen stage relative to the postsen stage $(p<0.05)$ and a significant increase during the postDH stage relative to the posthab stage $(p<0.01)$.

Input resistance of the S-cell changed during training in preparations from the habituation group but not in those from the sensitization group. During sensitization training, there was a small but statistically insignificant increase in the normalized $\mathrm{S}$-cell input resistance during the postsen stage (Fig. 5C). The normalized input resistance did not change between the postsen and endsen experimental stages. However, after habituation training there was a significant decrease in the input resistance relative to the initial baseline that reversed after dishabituation of the preparation (Fig. 5C). Two-way ANOVA did detect a signif- icant group effect in the normalized S-cell input resistances between the sensitization and habituation group $\left(F_{(1,38)}=7.90\right.$; $p<0.01)$, but no effect of experimental stage $\left(F_{(1,38)}=0.83\right)$ or group/stage interaction effect $\left(F_{(1,38)}=1.40\right)$.

Thus, S-cell excitability increased in preparations that underwent sensitization training. Significant enhancement was seen in both measures of excitability: initiation threshold and the number of action potentials elicited during the long stimulus pulse. Enhanced S-cell excitability had attenuated somewhat by the end of the sensitization experiment (endsen) and had returned to near baseline levels. It is unclear whether this decrease in S-cell excitability relative to the sensitized levels was caused simply by sensitization wearing off, but it is likely caused in part by the repetitive stimulation, which reduced the excitability of the S-cell. No change in S-cell input resistance was observed during sensitization training. S-cell excitability decreased in preparations that underwent habituation training. Although this change was not as robust as the changes observed in the sensitization group, this decrease in excitability was reversed by dishabituation. S-cell input resistance also decreased after habituation training and this change in input resistance was reversed by dishabituation training.

\section{HT effects: concentration series}

The effects of 5HT on S-cell excitability were determined at various concentrations. Bath application of high and intermediate 5HT concentrations (10 and $1.0 \mu \mathrm{M}$, respectively) reduced the S-cell initiation threshold, whereas thresholds of S-cells from the control group, which were treated with only normal saline, did not change throughout the duration of the testing period (Fig. 6 A). The maximum reduction in threshold for both 10 and $1.0 \mu \mathrm{M} 5 \mathrm{HT}$ occurred $\sim 4-6$ min after bath application of 5HT at each concentration and returned to baseline levels 20-22 min after washout. However, the initiation threshold increased in S-cells treated with a lower concentration of $0.1 \mu \mathrm{M} 5 \mathrm{HT}$, with the maximum change observed $\sim 12 \mathrm{~min}$ after application. The increased threshold began to return to normal $\sim 28$ min after 5 HT application but remained greater than initial baseline levels. Concentration-specific effects of 5HT on initiation threshold were confirmed statistically using two-way ANOVA to examine the effects of 5HT concentration and time. This analysis detected a statistically significant effect of concentration $\left(F_{(3,134)}=15.16\right.$; $p<0.0001)$, no significant effect of trial $\left(F_{(9,134)}=1.76\right)$, and no significant concentration-trial interaction effect $\left(F_{(27,134)}=0.94\right)$. Post hoc analysis of the 5HT concentration effect confirmed that the initiation thresholds from the high and the intermediate 

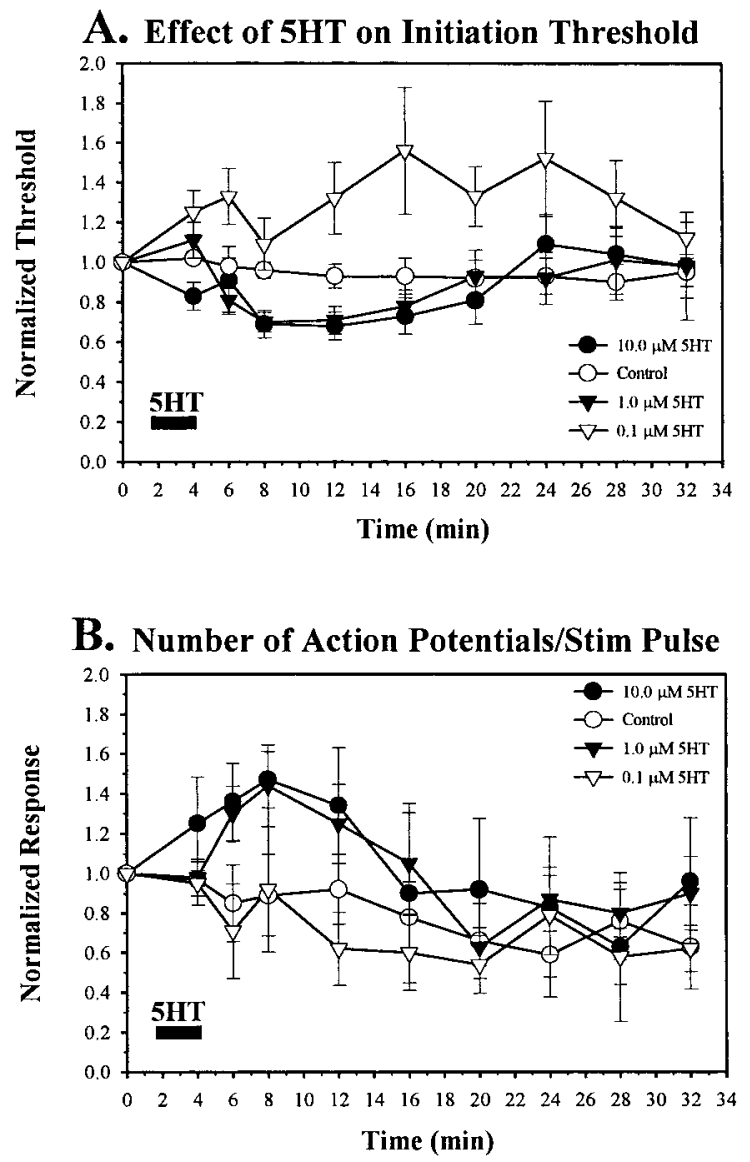

Figure 6. 5HT concentration series. Effects of saline $(\bigcirc)$ and with $0.1 \mu \mathrm{M}$ $(\triangle), 1.0 \mu \mathrm{M}(\bullet)$, and $10 \mu \mathrm{M}(\mathbf{\Delta}) 5 \mathrm{HT}$ on S-cell excitability as measured by initiation threshold (level of $25 \mathrm{msec}$ current pulse) $(A)$ and the number of action potentials elicited by a $250 \mathrm{msec}$ current pulse $(B)$. Values were normalized to those recorded initially for each S-cell.

concentration groups were significantly lower than those observed from the control $(p<0.05)$ and low concentration $(p<0.0001)$ groups. In addition, the initiation threshold from the low concentration group was significantly higher than that of the control group $(p<0.001)$.

An effect of 5HT was observed also in the second measure of excitability used in this same group of S-cells: the number of action potentials produced during a long stimulation pulse at a fixed magnitude. In the high concentration group, there was a significant increase in the number of action potentials initiated during the long stimulus pulse (Fig. 6B). An increase in the number of initiated action potentials was also observed in the intermediate concentration group, but this did not reach statistical significance (see analysis below). No difference in the number of action potentials initiated was observed between the low concentration and the control groups. A two-way ANOVA (concentration and time) did confirm an effect of 5HT concentration $\left(F_{(3,123)}=3.82 ; p<0.05\right)$; however, post hoc analysis showed that only the high concentration group was significantly different from the control and low concentration groups $(p<0.05)$. The number of action potentials elicited decreased to $\sim 75 \%$ of the initial level when the last test was made in both the control and low concentration groups (Fig. 6B). Also, responses in the high and intermediate concentration groups converged to approximately the level of the control groups by the latter stages of this experiment.
This reduction in the number of action potentials fired during the stimulus pulse across the four experimental groups suggests a decrease in the excitability of the S-cell during the recording period that was unrelated to the 5HT treatment. However, the two-way ANOVA conducted on these data indicated no statistically significant effect of experimental time $\left(F_{(9,123)}=1.95\right)$, nor was there a significant interaction effect between concentration and time $\left(F_{(27,123)}=0.40\right)$.

The increased number of action potentials elicited by a long depolarizing stimulus perhaps did not reach statistical significance in the $1.0 \mu \mathrm{M} 5 \mathrm{HT}$ group because of the decline in the ability of the S-cell to fire a train of action potentials. At the lower $5 \mathrm{HT}$ concentrations of $0.1 \mu \mathrm{M}$, which increased S-cell initiation threshold, indicating a decrease in excitability, a significant decrease in the number of action potentials elicited by the long stimulus pulse was not observed. One potential explanation is that 5HT-induced inhibition reduces the initial excitability of the $\mathrm{S}$-cell, but once the $\mathrm{S}$-cell is firing, $0.1 \mu \mathrm{M} 5 \mathrm{HT}$ does not reduce subsequent action potential initiation. Alternatively, it is possible that the progressive decline in the ability of the S-cell to fire trains of action potentials obscured any inhibitory effect of $0.1 \mu \mathrm{M} 5 \mathrm{HT}$.

\section{HT effects: metal microelectrode experiments}

The effect of 5HT on initiation threshold was also tested using a sharpened metal microelectrode to stimulate selectively the S-cell soma while recording the response of the interneuron with a suction electrode on the connective nerve. This stimulation technique is less invasive than with an intracellular electrode and allowed for longer observation times. Three groups of S-cells were tested: one perfused 2 min with $1.0 \mu \mathrm{M}$ 5HT (which corresponds to the intermediate concentration in the previous experiment), a second perfused 4 min with $1.0 \mu \mathrm{M} 5 \mathrm{HT}$, and a third perfused with saline alone. Both the 2 and 4 min 5HT application decreased the action potential initiation threshold (Fig. 7A). During washout, the initiation threshold in S-cells that had received a 2 min 5HT exposure returned to baseline levels $\sim 50 \mathrm{~min}$ after treatment, whereas those that received a 4 min exposure did not return to baseline during the entire $1 \mathrm{hr}$ washout period. Threshold for S-cells in the control group did not change. A two-way ANOVA was performed to test for the effects of different durations of 5HT application and experimental time. This analysis confirmed an effect of 5HT treatment on S-cell initiation threshold $\left(F_{(2,272)}=80.51 ; p<0.0001\right)$, with post hoc analysis stating that both 2 and 4 min exposure groups were significantly different from the control group $(p<0.0001)$ and that the 2 and $4 \mathrm{~min}$ groups were significantly different from each other $(p<0.0001)$. There was no statistically significant time effect $\left(F_{(16,272)}=0.54\right)$ or 5HT treatment-experimental time interaction effect $\left(F_{(32,272)}\right.$ $=1.24)$.

To determine whether the modulatory effects of $5 \mathrm{HT}$ on the S-cell were direct, a second group of S-cells was treated with 5HT for $4 \mathrm{~min}$ in $15 \mathrm{mM} \mathrm{MgCl}_{2}$ saline to prevent chemical synaptic transmission. For each S-cell, the initiation threshold was first measured in normal saline. As $15 \mathrm{mM} \mathrm{MgCl}_{2}$ saline was perfused through the recording chamber, the S-cell initiation threshold increased until a steady-state level was reached, $\sim 18 \mathrm{~min}$ after the beginning of $15 \mathrm{~mm} \mathrm{MgCl}_{2}$ saline application (Fig. $7 B$ ). After a 4 min application of $1.0 \mu \mathrm{M} 5 \mathrm{HT}$ in $15 \mathrm{~mm} \mathrm{MgCl}_{2}$ saline, the initiation threshold decreased and remained lower than pre-5HT treatment levels for the remainder of the experiment. The initiation threshold for control group S-cells did not change. For analysis purposes, data from the control and 5HT group were 


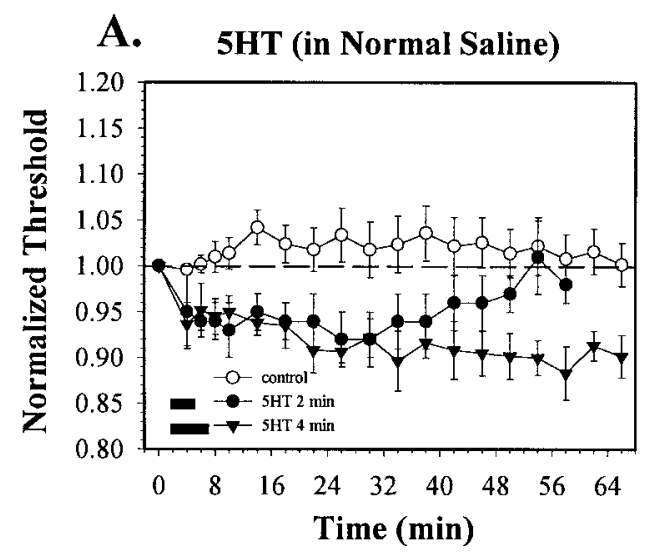

\section{B. 5HT (in $15 \mathrm{mM} \mathrm{MgCl}_{2}$ Saline)}

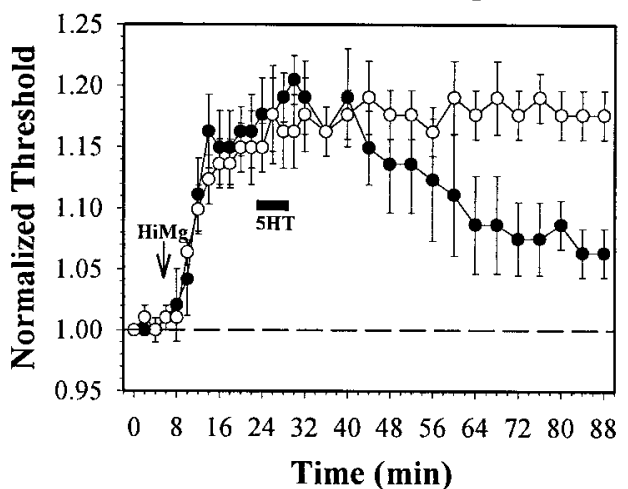

Figure 7. Metal microelectrode experiments. $A$, Effects of $2 \min (\mathbf{\Delta})$ and $4 \mathrm{~min}(\bullet)$ bath application of $1.0 \mu \mathrm{M} 5 \mathrm{HT}$ on S-cell initiation threshold. S-cells in the control group $(\bigcirc)$ were constantly perfused with normal saline. $B$, Effects of $1.0 \mu \mathrm{M} 5 \mathrm{HT}$ (4 min application) on S-cell excitability in the presence of $15 \mathrm{mM} \mathrm{MgCl}_{2}$ saline. S-cell initiation threshold from both the treatment group $(\bullet)$ and the control group $(\bigcirc)$ was initially tested in normal saline. The normal saline was then replaced with $15 \mathrm{~mm} \mathrm{MgCl}_{2}$ saline (arrow), and $5 \mathrm{HT}$ dissolved in $15 \mathrm{~mm} \mathrm{MgCl}_{2}$ saline was bath-applied 18 min later. Measurements of initiation threshold were normalized to the initial levels for each experiment.

A. Initiation Threshold

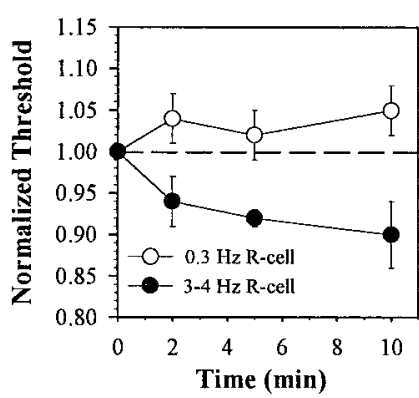

B. Action Potentials/

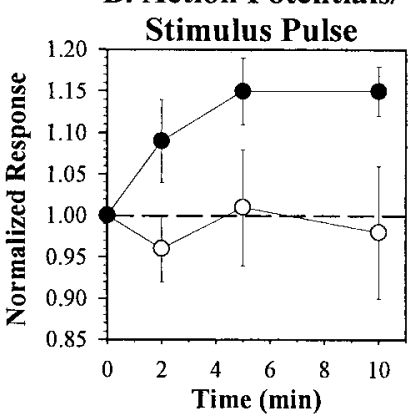

C. Input Resistance

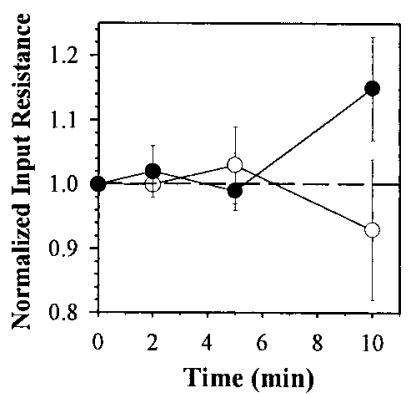

Figure 8. Effects of Retzius cell stimulation on S-cell excitability. S-cells were tested before (0 min) and 2, 5, and 10 min after Retzius cell stimulation at $3-4 \mathrm{~Hz}(\bigcirc)$ and $0.3 \mathrm{~Hz}(\bigcirc)$. Changes in S-cell initiation threshold $(A)$, number of action potentials elicited by a $200 \mathrm{msec}$ current pulse $(B)$, and input resistance $(C)$ were measured. All S-cell measurements were normalized to values taken before Retzius cell stimulation.

compared from the time point just before 5HT treatment to the end of the experiment (24-88 min). Two-way ANOVA revealed a significant effect of treatment (5HT vs control; $F_{(1,176)}=19.52$; $p<0.0001)$ and no significant time effect $\left(F_{(18,176)}=0.93\right)$ or treatment-time interaction $\left(F_{(18,176)}=1.50\right)$.

These experiments confirm, in a less invasive manner, that 1.0 $\mu \mathrm{M} 5 \mathrm{HT}$ increases S-cell excitability. As in the concentration series experiments, bath application of this concentration of 5HT lowered the initiation threshold of the S-cell, and longer 5HT exposures produced a longer-lasting enhancement. In addition, that $5 \mathrm{HT}$ enhanced excitability in $15 \mathrm{~mm} \mathrm{MgCl}_{2}$ saline confirmed that 5HT directly acted on the S-cell rather than through serotonergic modulation of another neuron(s) that then altered S-cell response properties.

\section{Retzius cell stimulation}

Intracellular stimulation of the 5HT-containing R-cell at 3-4 Hz for $10 \mathrm{sec}$ increased S-cell excitability in a manner similar to increases observed in the concentration series and with metal microelectrodes. In all cases in which a change in an excitability parameter was observed, the change began to occur within seconds of R-cell stimulation and lasted for at least $10 \mathrm{~min}$. S-cell initiation threshold significantly decreased after $3-4 \mathrm{~Hz}$ R-cell stimulation, but not after $0.3 \mathrm{~Hz}$ stimulation (Fig. $8 A$ ). Two-way ANOVA detected a significant effect of R-cell stimulation fre- quency $\left(F_{(1,32)}=23.57 ; p<0.0001\right)$, no effect of trial $\left(F_{(1,32)}=\right.$ $0.66)$, and a significant frequency-trial interaction effect $\left(F_{(1,32)}=\right.$ 3.10; $p<0.05)$ on the threshold of the S-cell. Post hoc analysis of the interaction effect revealed a significant difference in threshold between the 3-4 Hz R-cell group and the $0.3 \mathrm{~Hz} \mathrm{R}$-cell group during the measurements taken $10 \mathrm{~min}$ after R-cell stimulation. The number of action potentials elicited during a $200 \mathrm{msec}$ stimulus pulse increased after 3-4 Hz R-cell stimulation relative to the $0.3 \mathrm{~Hz}$ R-cell stimulation group (Fig. $8 B$ ). Two-way ANOVA detected a significant effect of R-cell stimulation frequency $\left(F_{(1,32)}=12.43 ; p<0.01\right)$ and no trial effect $\left(F_{(1,32)}=\right.$ $1.29 ; p \geq 0.05)$ or interaction effect $\left(F_{(1,32)}=1.44\right)$. S-cell input resistance was not affected by R-cell stimulation at either frequency (Fig. 8C). Two-way ANOVA detected no significant effects of R-cell stimulation frequency $\left(F_{(1,32)}=1.43\right)$ or trial $\left(F_{(1,32)}=0.21\right)$ and no interaction effect $\left(F_{(1,32)}=2.18\right)$.

These changes, a decrease in initiation threshold and an increase in the number of action potentials fired during a long depolarization pulse, were nearly identical to those produced by bath application of 1.0-10 $\mu \mathrm{M}$ 5HT. The frequency of R-cell firing that produced an observable potentiation of S-cell excitability is the same as that observed to elicit fictive swimming in isolated nerve cords (Willard, 1981), although the duration of R-cell activity was much shorter in the present experiments. The 


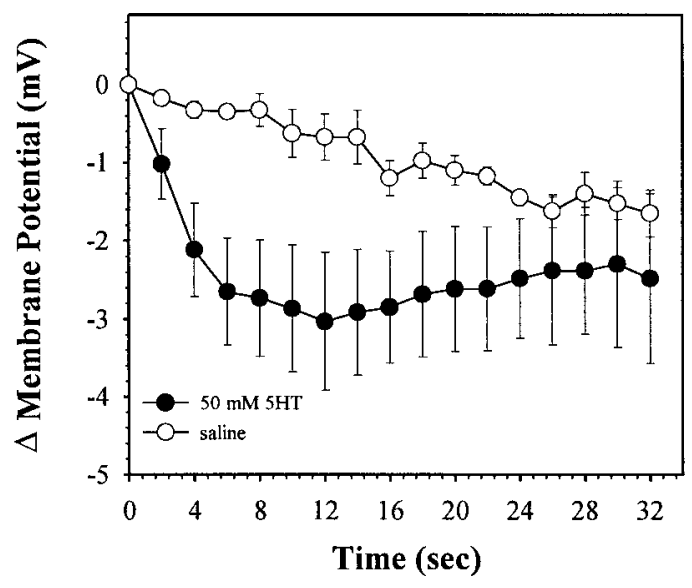

Figure 9. Effects of 5HT during direct soma application. Changes in S-cell resting potential immediately after direct application of $50 \mathrm{~mm} 5 \mathrm{HT}$ (๑) or $15 \mathrm{mM} \mathrm{MgCl}_{2}$ saline $(\bigcirc)$ onto the S-cell soma.

R-cell-induced modulation is almost certainly caused by 5HT, because no other neurotransmitters are known to be released by this neuron (Stuart et al., 1974; Henderson, 1983). No inhibitory effects were observed in the S-cell after R-cell stimulation at either 0.3 or $3-4 \mathrm{~Hz}$.

\section{Focal application of 5HT}

Direct application of a pulse of $50 \mathrm{~mm} 5 \mathrm{HT}$ from a micropipette onto the S-cell soma in a recording chamber with constant flow consistently produced a rapid hyperpolarization of the S-cell resting potential by $\sim 3 \mathrm{mV}$ (Fig. 9). This change in resting potential was not observed in S-cells during a similar application of saline alone. Two-way ANOVA detected a significant 5HT effect $\left(F_{(1,128)}=36.58 ; p \leq 0.0001\right)$, but no significant time effect $\left(F_{(15,128)}=0.53\right)$ or treatment-time interaction effect $\left(F_{(18,128)}=\right.$ $0.37)$. This $5 \mathrm{HT}$-induced hyperpolarization of the S-cell occurred when synaptic transmission was blocked by bathing the tissue in $15 \mathrm{mM} \mathrm{MgCl}_{2}$ saline and was therefore a direct modulatory effect of 5HT. Application of 5HT from a pipette filled with $25 \mathrm{~mm} 5 \mathrm{HT}$ produced a smaller hyperpolarization of the S-cell (data not shown). Although the exact concentration of 5HT that reached the S-cell using this pressure-ejection procedure is not known, it is unlikely that the lack of an excitatory effect was caused by the delivery of insufficient amounts of 5HT. When the same protocol was used to apply $5 \mathrm{HT}$ on the P-cell soma, substantial depolarization of the P-cell was observed (data not shown), as described previously by Henderson (1983).

\section{DISCUSSION}

\section{Dual effects are mediated by different $5 \mathrm{HT}$ receptors}

That 5HT both excited and inhibited the S-cell indicates that at least two different 5HT receptors may be present, as in single hippocampal and prefrontal cortex neurons (Andrade and Nicoll, 1987; Colino and Halliwell, 1987; Araneda and Andrade, 1991), spinal motor neurons (White, 1985; Skydsgaard and Hounsgaard, 1996), and leech mechanosensory $\mathrm{P}$ cells (Henderson, 1983; Drapeau and Sanchez-Armass, 1988), for example. In the leech P-cells, application of low levels of 5HT onto the soma produces hyperpolarization of the membrane potential that may be mediated by a $5 \mathrm{HT}_{3}$ receptor (Ali et al., 1998), whereas more 5HT induces depolarization resulting from the activation of a $5 \mathrm{HT}_{2}$ like receptor (Catarsi and Drapeau, 1997). The two 5HT receptor populations appear to be differentially distributed between the synaptic and extrasynaptic regions of the P-cell. In situ, stimulation of the 5HT-containing R-cell produces only IPSPs in the P-cell, whereas direct application of sufficient 5HT onto the soma depolarizes it (Fuchs et al., 1982; Henderson, 1983).

There is evidence that for the S-cell, like the P-cell, inhibitory and excitatory $5 \mathrm{HT}$ receptors are differentially distributed over the cell surface. Focal application of 5HT onto the S-cell soma elicited only hyperpolarization, suggesting that the excitatory $5 \mathrm{HT}$ receptors of the $\mathrm{S}$-cell were distant from soma in the neuropil. In contrast, 3-4 Hz stimulation of the R-cell, the presynaptic terminals of which are in the neuropil, enhanced S-cell excitability and was not inhibitory even at a low $(0.3 \mathrm{~Hz})$ firing frequency. Perhaps inhibition of the S-cell at low concentrations of 5HT mimicked the action of R-cell-released 5HT circulating in the blood (Willard, 1981) and that such concentrations were not reached in the volume of the recording chamber during R-cell stimulation. On the other hand, it is possible that frequencies or durations of R-cell activity not tested in the present experiments inhibit the S-cell or that activity from other 5HT-containing neurons may inhibit the S-cell. Another alternative, that the 5HT applied focally on the S-cell soma might be insufficient to be excitatory, similar to what is observed when low-concentration $5 \mathrm{HT}$ is bath-applied, seems unlikely because (1) hyperpolarization occurred over a range of applications and (2) the same amount of focally applied 5HT strongly depolarized the P-cell.

During bath application of 5HT, both types of receptors were accessible; inhibitory and excitatory effects of 5HT could be distinguished by adjusting the transmitter concentration. Inhibition at the lower concentration $(0.1 \mu \mathrm{M})$ was consistent with inhibitory receptors having a higher affinity for 5HT than excitatory receptors. Ionic mechanisms for inhibition are unknown in the S-cell, but in the $\mathrm{P}$-cell involve an increase in $\mathrm{Cl}^{-}$conductance (Ali et al., 1998). At higher concentrations (1-10 $\mu \mathrm{M})$, only the excitatory effect was observed, possibly because the inhibitory 5HT receptors rapidly desensitized (Henderson, 1983; Drapeau and Sanchez-Armass, 1988) or because the magnitude of the 5HT-induced excitatory effect may have obscured the inhibitory effect. Again, the ionic mechanisms for excitation are unknown in the S-cell, but in the P-cell excitation is mediated by an increase in a nonspecific monovalent cation conductance (Sanchez-Armass et al., 1991).

\section{Relevance of the effects of $5 \mathrm{HT}$ for non-associative learning}

The results support the hypothesis that sensitization and dishabituation of the leech whole-body shortening reflex are produced, at least in part, by serotonergic modulation of the S-cell, enhancing the activity of the interneuron and its contribution to the elicited shortening response. This hypothesis is based on earlier observations showing that 5HT depletion from the leech CNS or lesions of the S-cell chain disrupted sensitization and partially disrupted dishabituation without affecting habituation of the shortening response or the capacity to shorten (Ehrlich et al., 1992; Sahley et al., 1994; Modney et al., 1997). The hypothesis is additionally supported by three observations during the current experiments. First, increased S-cell excitability after sensitization and dishabituation training was similar to the enhancement observed after bath application of 1-10 $\mu \mathrm{M}$ 5HT onto the S-cell. 5HT-induced enhancement of S-cell excitability could explain increased evoked S-cell activity during sensitization and dishabituation of the shortening reflex. Second, the excitatory effects of 
exogenously applied 5HT persisted beyond the period of exposure to the neurotransmitter. This is significant because it shows that increased S-cell excitability persists long after delivery of the sensitizing stimulus that presumably induces 5 HT release. Third, stimulation of 5HT-containing R-cells increased S-cell excitability in a manner similar to exogenous 5HT application at sufficient concentrations or after sensitization or dishabituation. This is relevant because $5 \mathrm{HT}$ depletion protocols that disrupt sensitization and dishabituation primarily deplete 5HT in the R-cells (Ehrlich et al., 1992).

Taken together, the data indicate that a noxious mechanosensory stimulus that causes sensitization or dishabituation of wholebody shortening reflex acts in part by inducing the release of 5HT, most likely from the R-cells, which modulates the electrical properties of the S-cell. 5HT is likely to reach the S-cell through a combination of release within the ganglion neuropil and as a circulating neurohormone within the blood. The increased S-cell excitability enhances the activity of the interneuron during evoked whole-body shortening responses. Increased S-cell activity (1) may enhance synaptic transmission from the S-cell by synaptic facilitation, temporal summation, or both; (2) may increase the probability of transmitter release at synapses that have a high rate of failure (Lisman, 1997), allowing the S-cell to excite a neuron that it might not excite in the unsensitized state; and (3) may enhance release of a modulatory neuropeptide (Vilim et al., 1996, 2000), such as myomodulin, which is found in the S-cell and known to have excitatory effects on the R-cells (Keating and Sahley, 1996; Wang et al., 1999). All of these changes could increase the participation of the S-cell in whole-body shortening and explain the enhanced contribution of the S-cell to the shortening reflex during sensitization or dishabituation.

Significantly, increased S-cell excitability persists long after bath-applied 5HT treatment has ended. This effect lasts longer than the increased excitability of Aplysia sensory cells after a $2 \mathrm{hr}$ application of 5HT (Liao et al., 1999). It is also longer than the increase in synaptic transmission at Aplysia sensory-to-motor neuron synapses produced by $5 \mathrm{HT}$ treatment for a period $(5 \mathrm{~min})$ comparable to that used in the present experiments (Sutton and Carew, 2000). This is of particular interest because increased exposure to serotonin produces progressively longer-lasting enhancements of synaptic transmission thought to represent distinct short-, intermediate-, and long-term memory processes in Aplysia (Montarolo et al., 1986; Ghirardi et al., 1995; Sutton and Carew, 2000). The duration of enhanced S-cell excitability after a 4 min $5 \mathrm{HT}$ treatment corresponds with what would be an intermediate form of neuroplasticity in Aplysia (30-180 min), which requires both prolonged exposure to $5 \mathrm{HT}$ and protein synthesis. However, the temporal characteristics of short-, intermediate-, and longterm memory in the leech shortening reflex have not been examined. If they are similar to those in Aplysia, then the present data suggest that intermediate forms of neuroplasticity, and perhaps the corresponding form of memory, in the leech may be induced by much shorter exposures to $5 \mathrm{HT}$.

Other actions of 5HT may also enhance S-cell firing during sensitization and dishabituation of the shortening reflex. 5HT has a wide range of excitatory effects in the leech nervous system including potentiation of the swimming (Willard, 1981; O'Gara et al., 1991; Angstaadt and Friesen, 1993; Groome et al., 1993) and feeding responses (Lent et al., 1991; O'Gara et al., 1991; Groome et al., 1993) (but see Wilson et al., 1996). 5HT depolarizes the P-cell (Henderson, 1983) and facilitates recovery of conduction block in mechanosensory cells (Catarsi and Brunelli, 1991; Mar and Drapeau, 1996), which enhances their synaptic transmission onto the S-cells (Muller and Scott, 1981; Baccus et al., 2000). 5HT may also increase neurotransmitter release, thereby facilitating synaptic transmission as in Aplysia (Hawkins et al., 1993). Dishabituation likely involves other neuromodulatory processes distinct from sensitization because dishabituation is only partially disrupted by lesions of the S-cell chain and 5HT depletion. This has also been reported for Aplysia, where dishabituation and sensitization arise at separate times during development (Rankin and Carew, 1988).

5HT-induced inhibition of the S-cell may be involved in nonassociative learning in the leech, specifically during habituation. Decreased S-cell excitability during habituation was similar to that observed after bath application of $0.1 \mu \mathrm{M}$ 5HT. Although 5HT depletion and lesions of the S-cell chain did not affect habituation of the leech whole-body shortening response (Ehrlich et al., 1992; Sahley, 1994), 5HT depletion did disrupt a recently described extrinsic, or heterosynaptic, form of habituation of this reflex (Burrell and Sahley, 1999). Extrinsic habituation describes a process in which repetitive stimulation produces a behavioral decrement through the actions of a heterosynaptic modulatory process as opposed to the homosynaptic depression typically associated with habituation (Davis and File, 1984). It is possible that in experiments where 5HT was depleted or the S-cell chain was lesioned (Ehrlich et al., 1992; Sahley et al., 1994; Modney et al., 1997), the contribution of 5HT-induced inhibition of the S-cell to habituation was compensated by other mechanisms acting in parallel during habituation training, such as homosynaptic depression observed in Aplysia (Castellucci et al., 1970), and was therefore not observed during standard habituation training. Using training protocols that produce extrinsic habituation (Burrell and Sahley, 1998), one can measure the roles of 5HT and the S-cell by use of selective S-cell lesions and pharmacological block of 5HT-induced S-cell inhibition during this form of learning.

\section{Conclusion}

These data provide strong evidence that postsynaptic modulation of neuron excitability can play as important a role in the physiological processes of learning as changes in neurotransmission. Changes in neuronal excitability during learning have been observed in other animals, including rabbit hippocampal neurons (Moyer et al., 1996; Thompson et al., 1996), rat cerebellar neurons (Armano et al., 2000), Hermissenda sensory neurons (Crow and Alkon, 1980; Frysztak and Crow, 1993), Helix interneurons (Gainutdinov et al., 1998), and Aplysia sensory neurons after delivery of a noxious stimulus (Clatworthy and Walters, 1993). In addition, serotonin enhances excitability in neurons known to contribute to learning and memory in both vertebrates and invertebrates (Klein et al., 1986; Andrade and Nicoll, 1987; Araneda and Andrade, 1991; Liao et al., 1999). Among the novel and significant features of the current experiments are the involvement of a single interneuron that is known to be essential for two types of non-associative learning: sensitization and full dishabituation. The observed changes in excitability that appear to be induced by $5 \mathrm{HT}$ during non-associative learning are consistent with the serotonergic modulation that contributes to associative as well as non-associative learning (Hawkins et al., 1993; Sahley, 1994). Non-associative increases in the excitability of a neuron may facilitate synapse-specific forms of neuroplasticity, such as long-term potentiation, that are thought to contribute to associative learning (Moyer et al., 1996). It remains to be determined what cellular and biophysical mechanisms underlie 5HT-induced 
changes in excitability, the consequences of those changes in other parts of the shortening circuit, and how they may mediate learning.

\section{REFERENCES}

Ali DW, Catarsi S, Drapeau P (1998) Ionotropic and metabotropic activation of a neuronal chloride channel by serotonin and dopamine in the leech Hirudo medicinalis. J Physiol (Lond) (Lond) 509:211-219.

Andrade R, Nicoll RA (1987) Pharmacologically distinct actions of serotonin receptors on single pyramidal neurones of the rat hippocampus recorded in vitro. J Physiol (Lond) 394:99-124.

Angstaadt JD, Friesen WO (1993) Modulation of swimming behavior in the medicinal leech: I. Effects of serotonin on the electrical properties of swim-gating cell 204. J Comp Physiol [A] 172:223-234.

Araneda R, Andrade R (1991) 5-Hydroxytrypatamine 2 and 5-hydroxytrypatamine ${ }_{1 \mathrm{~A}}$ receptors mediate opposing responses on membrane excitability in rat association cortex. Neuroscience 40:399-412.

Armano S, Rossi P, Tagliette V, D'Angelo E (2000) Long-term potentiation of intrinsic excitability at the mossy fiber-granule cell synapse of rat cerebellum. J Neurosci 20:5208-5216.

Baccus SA, Burrell BD, Sahley CL, Muller KJ (2000) Action potential reflection and failure at axon branch points produce stepwise changes in synaptic transmission to an interneuron essential for learning. J Neurophysiol 83:1693-1700.

Bagnoli P, Brunelli M, Magni F (1972) A fast conducting pathway in the central nervous system of the leech Hirudo medicinalis. Arch Ital Biol 110:35-51.

Burrell BD, Sahley CL (1998) Generalization of habituation and intrinsic sensitization in the leech. Learn Mem 5:405-419.

Burrell BD, Sahley CL (1999) Serotonin depletion does not prevent intrinsic sensitization in the leech. Learn Mem 6:509-520.

Castellucci VF, Pinsker H, Kupferman I, Kandel ER (1970) Neuronal mechanisms of habituation and dishabituation of the gill-withdrawal reflex in Aplysia. Science 167:1745-1748.

Catarsi S, Brunelli M (1991) Serotonin depresses the afterhyperpolarization through the inhibition of the $\mathrm{Na}^{+} / \mathrm{K}^{+}$electrogenic pump in T sensory neurones of the leech. J Exp Biol 155:261-273.

Catarsi S, Drapeau P (1997) Requirement for tyrosine phosphatase during serotonergic neuromodulation by protein kinase C. J Neurosci 17:5792-5797.

Clatworthy AL, Walters ET (1993) Rapid amplification and facilitation of mechanosensory discharge in Aplysia by noxious stimulation. J Neurophysiol 70:1181-1194.

Colino A, Halliwell JV (1987) Differential modulation of three separate K-conductances in hippocampal CA1 neurons by serotonin. Nature 328:73-77.

Crow T, Alkon DL (1980) Associative behavioral modification in Hermissenda: cellular correlates. Science 209:412-414.

Davis M, File SE (1984) Intrinsic and extrinsic mechanisms of habituation and sensitization: implications for the design and analysis of experiments. In: Habituation, sensitization, and behavior (Peeke HVS, Petrinovich LF, eds), pp 287-323. New York: Academic.

Drapeau P, Sanchez-Armass S (1988) Selection of postsynaptic serotonin receptors during reinnervation of an identified leech neuron in culture. J Neurosci 8:4718-4727.

Ehrlich J, Boulis N, Karrer T, Sahley CL (1992) Differential effects of serotonin depletion on sensitization and dishabituation. J Neurobiol 23:270-279.

Esch T, Kristan WB (1999) Neuronal control of behavioral choice in the medicinal leech. Soc Neurosci Abstr 25:146.10.

Frysztak RJ, Crow T (1993) Differential expression of correlates of classical conditioning in identified medial and lateral type A photoreceptors of Hermissenda. J Neurosci 13:2889-2897.

Fuchs P, Henderson LP, Nicholls JG (1982) Chemical transmission between individual Retzius and sensory neurones of the leech in culture. J Physiol (Lond) 323:195-210.

Gainutdinov KL, Chekmarev LJ, Gainutdinov TH (1998) Excitability increase in withdrawal interneurons after conditioning in snail. NeuroReport 9:517-520.

Gardner-Medwin AR, Jansen JK, Taxt T (1973) The "giant" axon of the leech. Acta Physiol Scand 87:30-31.

Ghirardi M, Montarolo PG, Kandel ER (1995) A novel intermediate stage in the transition between short- and long-term facilitation in the sensory to motor neuron synapse of Aplysia. Neuron 14:413-420.

Groome JR, Clark M, Lent CM (1993) The behavioural state of satiation in the leech is regulated by body distension and mimicked by serotonin depletion. J Exp Biol 182:265-270.

Grumbacher-Reinert S, Nicholls J (1992) Influence of substrate on retraction of neurites following electrical activity of leech Retzius cells in culture. J Exp Biol 167:1-14.

Hawkins RD, Kandel ER, Siegelbaum SA (1993) Learning to modulate transmitter release: themes and variations in synaptic plasticity. Annu Rev Neurosci 16:625-665.

Henderson LP (1983) The role of 5-hydroxytryptamine as a transmitter between identified leech neurones in culture. J Physiol (Lond) 339:309-324.

Hubel D (1957) Tungsten microelectrode for recording from single units. Science 123:549-550.

Keating HH, Sahley CL (1996) Localization of the myomodulin-like immunoreactivity in the leech CNS. J Neurobiol 30:374-384.

Klein M, Hochner B, Kandel ER (1986) Facilitatory transmitters and cAMP can modulate accommodation as well as transmitter release in Aplysia sensory neurons: evidence for parallel processing in a single cell. Proc Natl Acad Sci USA 83:7994-7998.

Kuffler SW, Potter DD (1964) Glia in the leech central nervous system: physiological properties and neuron-glia relationship. J Neurophysiol 27:290-320.

Laverack MS (1969) Mechanoreceptors, photoreceptors and rapid conduction pathways in the leech Hirudo medicinalis. J Exp Biol 50:129-140.

Lent CM, Zundel D, Freedman E, Groome JR (1991) Serotonin in the leech central nervous system: anatomical correlates and behavioral effects. J Comp Physiol 168:191-200.

Liao X, Brou CG, Walters ET (1999) Limited contributions of serotonin to long-term hyperexcitability of Aplysia sensory neurons. J Neurophysiol 82:3223-3235.

Lisman JE (1997) Bursts as a unit of neural information: making unreliable synapses reliable. Trends Neurosci 20:38-43.

Magni F, Pelligrino M (1978) Neural mechanisms underlying the segmental and generalized cord shortening reflexes in the leech. J Comp Physiol 124:339-351.

Malenka RC, Nicoll RA (1999) Long-term potentiation: a decade of progress? Science 285:1870-1874.

Mar A, Drapeau P (1996) Modulation of conduction block in leech mechanosensory neurons. J Neurosci 16:4335-4343.

Modney BK, Sahley CL, Muller K J (1997) Regeneration of a central synapse restores nonassociative learning. J Neurosci 17:6478-6482.

Montarolo PG, Goelet P, Castellucci VF, Morgan J, Kandel ER, Schacher S (1986) A critical period for macromolecular synthesis in long-term heterosynaptic facilitation in Aplysia. Science 234:1249-1254.

Moyer JR, Thompson LT, Disterhoft JF (1996) Trace eyeblink conditioning increases CA1 excitability in a transient and learning-specific manner. J Neurosci 16:5536-5546.

Muller KJ, Scott SA (1981) Transmission at a "direct" electrical connexion mediated by an interneurone in the leech. J Physiol (Lond) 311:565-583.

Nicholls JG, Purves D (1970) Monosynaptic chemical and electrical connexions between sensory and motor cells in the central nervous system of the leech. J Physiol (Lond) 209:647-667.

O'Gara BA, Chae H, Latham LB, Friesen WO (1991) Modification of leech behavior patterns by reserpine-induced amine depletion. J Neurosci 11:96-110.

Rankin EA, Carew TJ (1988) Dishabituation and sensitization emerge as separate processes during development in Aplysia. J Neurosci 8:197-211.

Sahley CL (1994) Serotonin depletion impairs but does not eliminate classical conditioning in the leech, Hirudo medicinalis. Behav Neurosci 108:1043-1052.

Sahley CL, Modney BK, Boulis NM, Muller KJ (1994) The S cell: an interneuron essential for sensitization and full dishabituation of leech shortening. J Neurosci 14:6715-6721.

Sanchez-Armass S, Merz DC, Drapeau P (1991) Distinct receptors, second messengers and conductances underlying the dual response to serotonin in an identified leech neuron. J Exp Biol 155:531-547.

Shaw BK, Kristan WB (1995) The whole-body shortening reflex of the medicinal leech: motor pattern, sensory basis, and interneuronal pathways. J Comp Physiol 177:667-681.

Shaw BK, Kristan WB (1999) Relative roles of the S cell network and parallel interneuronal pathways in the whole-body shortening reflex of the medicinal leech. J Neurophysiol 82:1114-1123.

Skydsgaard M, Hounsgaard J (1996) Multiple actions of iontophoretically applied serotonin on motorneurones in the turtle spinal cord in vitro. Acta Physiol Scand 158:301-310.

Stuart AE, Hudspeth AJ, Hall ZW (1974) Vital staining of specific monoamine-containing cells in the leech nervous system. Cell Tissue Res 153:55-61.

Sutton MA, Carew TJ (2000) Parallel molecular pathways mediate expression of distinct forms of intermediate-term facilitation at tail sensory-motor synapses in Aplysia. Neuron 26:219-231.

Thompson LT, Moyer Jr JR, Disterhoft JF (1996) Transient changes in excitability of rabbit CA3 neurons with a time course appropriate to support memory consolidation. J Neurophysiol 76:1836-1849.

Thompson RF, Groves PM, Teyler TJ, Roemer RA (1973) A dualprocess theory of habituation: theory and behavior. In: Habituation (Peeke HVS, Herz MJ, eds), pp 239-271. Orlando, FL: Academic.

Vilim FS, Cropper EC, Price D, Kupfermann I, Weiss KR (1996) Re- 
lease of peptide cotransmitters in Aplysia: regulation and functional implications. J Neurosci 16:8105-8114.

Vilim FS, Cropper EC, Price D, Kupfermann I, Weiss KR (2000) Peptide cotransmitter release from motorneuron B16 in Aplysia californica: costorage, corelease, and functional implications. J Neurosci 20:2036-2042.

Wang Y, Strong JA, Sahley CL (1999) Modulatory effects of myomodulin on the excitability and membrane currents in Retzius cells of the leech. J Neurophysiol 216-225.
White SR (1985) A comparison of the effects of serotonin, substance $\mathrm{P}$ and thyrotropin-releasing hormone on excitability of rat spinal motoneurons in vivo. Brain Res 335:63-70.

Willard AL (1981) Effects of serotonin on the generation of the motor program for swimming by the medicinal leech. J Neurosci 1:936-944. Wilson RJA, Kristan Jr WB, Kleinhaus AL (1996) An increase in activity of serotonergic Retzius neurones may not be necessary for the consummatory phase of feeding in the leech Hirudo medicinalis. J Exp Biol 199:1405-1414. 